\title{
PRINCÍPIO DA PRESUNÇÃO DE INOCÊNCIA E A DECISÃO PROFERIDA PELO SUPREMO TRIBUNAL FEDERAL NO HABEAS CORPUS No 126.292
}

Karine Aparecida Dias de Almeida ${ }^{1}$ Alessandro Dorigon ${ }^{2}$

ALMEIDA, K. A. D. de; DORIGON, A. Princípio da presunção de inocência e a decisão proferida pelo Supremo Tribunal Federal no habeas corpus $\mathrm{n}^{\circ}$ 126.292. Rev. Ciênc. Juríd. Soc. UNIPAR. Umuarama. v. 20, n. 2, p. 239-272, jul./dez. 2017.

RESUMO: Os princípios constitucionais são essenciais como fonte do Direito Brasileiro, tendo como objetivo principal servir de base ao ordenamento jurídico. Desse modo, tem-se o Princípio da Presunção de Inocência, que apresenta o marco inicial do cumprimento de pena, sendo cláusula pétrea, deve ser analisado de acordo com o texto constitucional. Todavia, ao julgar o Habeas Corpus $n^{\circ} 126.292$ não foi esse o entendimento do Supremo Tribunal Federal, vez que modificou de maneira diametralmente oposta entendimento firmado em Jurisprudência consolidada há anos, permitindo, agora, o cumprimento de pena antes de a sentença penal condenatória transitar em julgado. Tal acontecimento deu-se no momento em que o Brasil passa por devasta crise política e judicial, razão pela qual, o novo posicionamento é apoiado por diversas pessoas, com conhecimento técnico ou não, que enxergam na decisão o fim da impunidade para aqueles que cometem crimes políticos, os chamados crimes de "colarinho branco". Todavia, salienta-se que o crime que deu ensejo ao novo posicionamento do Tribunal, nem mesmo se compara à referida modalidade de crimes citada (sendo o infrator condenado ao crime de roubo qualificado). Sabendo que o Supremo Tribunal Federal tem o dever de guarda da Constituição, e que, ao achar pertinente, o Pretório Excelso julga de forma inconstitucional a fim de atender a anseios sociais (ignorando a Norma para tal), tem-se que o mesmo age em total controvérsia quanto aos seus ideais.

PALAVRAS-CHAVE: Constitucionalidade; Habeas Corpus; Presunção de Inocência; Princípios; Processo Penal.

DOI: $10.25110 /$ rcjs.v20i2.2017.6743

${ }^{1}$ Bacharel em Direito. Endereço Residencial: Rua Izidoro Ferreira da Silva, 530, Paranavaí - Paraná. E-mail:k.almeeida@hotmail.com

${ }^{2}$ Alessandro Dorigon. Mestre em direito. Endereço: Av. Presid. Castelo Branco, 3806, sala 503, Umuarama - Paraná. E-mail: alessandrodorigon@hotmail.com 


\section{INTRODUÇÃO}

O objetivo desta pesquisa é desenvolver uma linha paralela entre o Princípio da Presunção de Inocência - e seu modo de interpretação -, em relação à decisão proferida pelo Supremo Tribunal Federal, em 16 de fevereiro de 2016, no Habeas Corpus $\mathrm{n}^{\circ}$ 126.292. Para tanto, se faz necessário elucidar a quem cabe o dever da guarda da Constituição Federal, bem como, apontar as Teorias que surgiram ao longo dos anos para resolver tal questão.

Para decidir questões relevantes, em muitas oportunidades, o Supremo recorre ao Ativismo Judicial desenfreado, situação em que ultrapassa os limites de suas atribuições típicas e legais.

Desse modo, deve-se observar até onde é correto que o Tribunal o faça, vez que para que se alcance a sua finalidade, qual seja a Justiça, essas decisões devem respeitar o texto constitucional e por consequência, as garantias previstas no referido diploma.

A Presunção de Inocência é uma dessas garantias constitucionais e um dos princípios basilares do Direito Processual Penal Brasileiro, vez que tutela a liberdade individual. Tem previsão no artigo $5^{\circ}$, inciso LVII da nossa Carta Magna e garante que, com exceção das prisões cautelares, ninguém poderá ser preso se não em virtude de sentença penal condenatória transitada em julgado.

Com a novel decisão do Supremo Tribunal Federal que autoriza o cumprimento provisório da pena, o tema passou a ser o centro de diversas discussões no meio jurídico, vez que há quem defenda o novo entendimento, com fundamentos respaldados na morosidade do atual sistema Judiciário/Processual Penal brasileiro, bem como, aqueles que realçam que a decisão exarada pelo Tribunal fere garantia constitucional, e ainda, que o órgão não pode ceder a pressões externas e julgar de modo a ignorar a clareza do texto constitucional.

O presente artigo visa a abordar tais discussões de cunho jurídico, explanando de forma clara a decisão tomada quando em discussão do referido $\mathrm{Ha}$ beas Corpus, bem como, ilustrar prováveis problemas que surgirão a partir do novo entendimento.

\section{DAS DECISÕES INCONSTITUCIONAIS DO STF}

\subsection{Conceito de Constitucionalidade e Inconstitucionalidade}

Inicialmente, antes de adentrar-se ao tema principal, faz-se basilar expor os conceitos de Constitucionalidade e Inconstitucionalidade, visto que integrarão toda a interpretação do presente trabalho.

A palavra Constitucionalidade deriva da palavra Constitucional, tendo 
esta como significado: "que está em conformidade com a Constituição, que não a desrespeita ou por ela é regido" (BUENO, 2007, p. 191).

Desse modo, é simples compreender a definição da palavra inconstitucionalidade, que por sua vez, tem origem na palavra Inconstitucional, que se entende como algo: "que se opõe ou vai de encontro a constituição (reunião das leis que regem uma nação) de um país; contrário à constituição" (BUENO, 2007, p. 429).

Ainda sobre a inconstitucionalidade, Denise Vargas (2010, p. 189-190) estabelece que de acordo com a natureza jurídica do objeto em análise, para este ser considerado inconstitucional, três devem ser os planos analisados: de existência, validade e eficácia.

Compreende-se no Plano de Existência o ato ou a lei que não possua os elementos essenciais para sua existência. Quanto à existência, esta é questionada pela autora visto que, se uma norma é inexistente não há razão para que o Judiciário se manifeste, pois ela é inexistente.

Quanto ao Plano de Validade a citada autora ensina que se um ato existe, deve ser observada sua validade. Para tanto, o ato ou lei deve possuir um agente competente; um objeto lícito; e a forma deve estar prescrita em lei (apud BARROSO, 2008, p. 12-13).

Por fim, em relação ao Plano de Eficácia entende-se que o ato ou a lei possui aptidão para surtir os efeitos esperados.

A inconstitucionalidade pode dar-se de duas formas: por ação e por omissão. Silva (2009, p. 47) nos ensina que, no primeiro caso "ocorre a produção de atos legislativos ou administrativos que contrariem normas ou princípios da constituição". De outro modo, a inconstitucionalidade por omissão ocorre nos casos em que a norma constitucional necessita de que sejam praticados atos legislativos que a tornem plenamente aplicável. O autor exemplifica:

A Constituição, por exemplo, prevê o direito de participação dos trabalhadores nos lucros e na gestão das empresas, conforme definido em lei, mas, se esse direito não se realizar, por omissão do legislador em produzir a lei aí a referida e necessária à plena aplicação da norma, tal omissão se caracterizará como inconstitucional. (SILVA, 2009, p. 47).

Seguindo este entendimento, nos pontifica Miranda (2001, p. 273-273) que constitucionalidade e inconstitucionalidade caracterizam conceitos muito próximos estando ambos interligados, ou seja, "a relação que se estabelece entre uma coisa - a Constituição - e outra coisa - um comportamento - que lhe está ou não conforme, que com ela é ou não compatível, que cabe ou não no seu sentido". 


\subsection{Controle de Constitucionalidade}

Mas afinal, como garantir que leis e atos normativos posteriores estejam de acordo com nossa Carta Magna?

Em resposta a este questionamento, foi criado o chamado Controle de Constitucionalidade, visando "verificar a adequação (compatibilidade) de uma lei ou de um ato normativo com a constituição, verificando seus requisitos formais e materiais" (MORAES, 2016. p. 1.120), pelo qual somente normas constitucionais positivadas serão utilizadas como parâmetro para a análise de constitucionalidade de atos normativos estatais e leis.

De mesmo modo, nas palavras de Denise Vargas (2010, p. 182-183) o controle de constitucionalidade é "um procedimento pelo qual órgãos constitucionais, na defesa da supremacia da Lei Maior, fiscalizam a compatibilidade das leis e atos com o conteúdo, com a forma e com o espírito da Constituição". Tal ação tem como finalidade protege-la de atos que possam arruinar o modo escalonado do ordenamento jurídico brasileiro.

Insta salientar que não apenas leis e atos normativos serão objetos do Controle de Constitucionalidade, como preleciona Pedro Lenza (2012, p. 129) citando entendimento do Supremo Tribunal Federal:

Em interessante precedente, estabelece a Suprema Corte: "Estão sujeitos ao controle de constitucionalidade concentrado os atos normativos, expressões da função normativa, cujas espécies compreendem a função regulamentar (do Executivo), a função regimental (do Judiciário) e a função legislativa (do Legislativo). Os decretos que veiculam ato normativo também devem sujeitar-se ao controle de constitucionalidade exercido pelo Supremo Tribunal Federal. O Poder Legislativo não detém o monopólio da função normativa, mas apenas de uma parcela dela, a função legislativa”.

Desta feita, tem-se que essas medidas podem ir desde a sustação de atos por órgãos constitucionais, como o Tribunal de Contas, por exemplo, à extinção da norma em desacordo com a Constituição, a exemplo de decisão do Supremo Tribunal Federal que declara, através de ação direta, a inconstitucionalidade de determinada lei (VARGAS, 2010, p. 183).

O Controle de Constitucionalidade pode ser entendido de acordo com a doutrina clássica e, nas palavras de Manoel Gonçalves Ferreira Filho (2012, p. 55), como um mecanismo que visa a adequação de um ato jurídico à Constituição. Abrangendo o exame tanto de requisitos formais (subjetivos - como a competência do órgão que a editou; ou objetivos como prazos, rito e a forma), quanto daqueles substanciais (em respeito às garantias fundamentais reconhecidos em 
nossa Constituição) de constitucionalidade de um ato jurídico.

\subsection{O Supremo Tribunal Federal como guardião da Constituição Federal}

A Constituição Federal (BRASIL, 1988) narra, no caput de seu artigo 102 que: "Compete ao Supremo Tribunal Federal, precipuamente, a guarda da Constituição [...]". Diante de tal assertiva, afirma-se que é o Supremo Tribunal Federal o "Guardião da Constituição", pois pertence a ele o dever de guarda da Carta Magna.

No que tange ao tema (a quem deve caber a guarda da Constituição) insta salientar que duas grandes correntes doutrinárias surgiram a fim de esclarecer o assunto e demonstrar a relação entre Direito e Política.

Em uma vertente, defendia o alemão Carl Schmitt, que somente o Presidente do Reich teria legitimidade para desempenhar a função de Guardião da Constituição, ou seja, a guarda da Lei Maior ficaria sob o poder de uma só pessoa: o representante máximo do povo, o Chefe do Estado. Seus argumentos se respaldavam na legitimidade democrática, uma vez que um líder eleito pelo povo poderia, de melhor maneira, ser o guardião da Constituição - tendo em vista que esta é feita para o próprio povo -, e tomar as decisões mais pertinentes a ele (SCHMITT, 2007, p. 09).

Corrente diversa, dominada pelo jurista austríaco Hans Kelsen (2003, p. 256-257), tinha como premissa o pensamento de que a guarda da Constituição teria de pertencer a um Supremo Tribunal, no qual um colegiado poderia, ao final de discussões, chegar às decisões que fossem mais corretas e justas para os cidadãos.

O ponto primordial de debate entre ambos, é que o segundo jurista alegava que o poder nas mãos de um único indivíduo causaria algo muito próximo a uma ditadura. Em contrapartida, Schmitt afirmava que, quando um conjunto de pessoas que não as eleitas pelo povo tomavam decisões para estes, a democracia estava sendo descartada.

Pelo exposto, resta evidente que o Direito Brasileiro, adotou a teoria empregada por Hans Kelsen, tendo em vista a narrativa do artigo 102 da Constituição Federal.

No Direito Brasileiro, o termo fora utilizado inicialmente ante a primeira Constituição Republicana, de 24 de fevereiro de 1891 pela qual, com grande influência da doutrina constitucional, introduziu-se nova concepção ao Poder Judiciário. Sendo confiada ao Supremo Tribunal Federal ainda, a competência para decisão de causas e conflitos entre a União e os Estados-membros, bem como a competência para aferir a constitucionalidade da aplicação do Direito através de um recurso especial (MENDES; COELHO; BRANCO, 2009, p. 981). 
Esclarecida tal divergência, cabe salientar qual seja o real sentido de guarda da Constituição.

De acordo com o dicionário da língua portuguesa, a palavra "guardar" pode ser definida como: o ato de conservar algo para o fim a que se destina; proteger; preservar.

Desse modo, tem-se que é dever do Supremo Tribunal Federal preservar a Constituição em conformidade com o fim a que ela se destina, qual seja, o de exercer sua função primária de estabelecer normas, deveres e direitos dos cidadãos de acordo com a vontade emanada do povo. Portanto, é palpável que não é dada a esta Corte o poder de alterar as normas constitucionais quando achar pertinente, mas o contrário: mantê-las de acordo com os princípios sociais, conservando-a para que possa salvaguardar a segurança jurídica.

\subsection{Ativismo judicial}

Não há na doutrina concepções seguras e uniformes a respeito da conceituação de Ativismo Judicial. Todavia, a maioria dos autores que abordam o assunto, afirmam que o termo trata-se de uma ação em que o Poder Judiciário vai além de suas atribuições comuns, ultrapassando os limites de sua típica competência.

O tema no Brasil é relativamente novo, vez que a primeira obra literária abordando exclusivamente o Ativismo Judicial fora lançada apenas em 2009, com autoria da Doutora Vanice Regina Lírio do Valle

Desse modo, pode-se definir "Ativismo Judicial" como o momento em que o Judiciário age além de seus poderes atribuídos pelo próprio ordenamento jurídico. Nesse sentido, Thamy Pogrebinschi (2000, p. 2), afirma ser ativista, o juiz que:
a) use o seu poder de forma a rever e contestar decisões dos demais poderes do estado; b) promova, através de suas decisões, políticas públicas; c) não considere os princípios da coerência do direito e da segurança jurídica como limites à sua atividade.

Todavia, a doutrina não é unânime quanto a concreta função do ativismo e sua contribuição para o sistema jurídico brasileiro. Parte afirma que o mesmo é um meio de garantir os direitos constitucionais, na inércia dos demais poderes. Neste sentido, tem-se o entendimento de Dirley da Cunha Júnior (2015) no sentido de que:

${ }^{3}$ VALLE, Vanice Regina Lírio do. Ativismo Jurisdicional e o Supremo Tribunal Federal. 1. ed. Curitiba: Juruá Editora, 2009. 
[...] quando os Poderes Legislativo e Executivo mostram-se incapazes ou totalmente omissos em garantir o cumprimento adequado dos direitos fundamentais, em violação evidente de seus deveres constitucionais, cabe inevitavelmente a intervenção do Judiciário, como o terceiro gigante no controle das omissões do poder público. Noutras palavras, quando os órgãos de direção política (Legislativo e Executivo) falham ou se omitem na implementação de políticas públicas destinadas à efetivação dos direitos fundamentais e dos objetivos fundamentais do art. $3^{\circ}$ da Constituição Federal de 1988, cumpre ao Poder Judiciário - co-responsável no processo de construção da sociedade do bem-estar - adotar uma posição ativa e dinâmica na realização das finalidades do Estado Social, desenvolvendo e efetivando diretamente os preceitos constitucionais definidores desses direitos sociais.

De outra maneira, corrente diversa, afirma que o ativismo apresenta uma contribuição negativa, vez que importa na desnaturação da típica atividade do Poder Judiciário, em detrimento dos demais (RAMOS, 2015, p. 131). Nesta mesma linha de pensamento, Lênio L. Streck (2014), afirma que o ativismo não é benigno para a democracia:

Ativismo é quando o Judiciário se substitui aos poderes que são do legislador e, por exemplo, acaba interferindo nas esferas dos demais Poderes e fazendo com que se fragmente o sistema. A judicialização acontece, em qualquer país do mundo e o ativismo acaba sendo ruim para a democracia. Acabamos criando o judiciário muito forte, como uma espécie de grande pai da nação. $\mathrm{O}$ ativismo é vulgata da judicialização.

É importante salientar que ativismo judicial não se confunde com judicialização da política, vez que, o primeiro refere-se a escolha da Corte ou do magistrado, que visa uma direta aplicação do texto constitucional, utilizando-se de métodos menos rigorosos de interpretação. Já no que tange à judicialização, tem-se que esta trata-se de casos nos quais, quem toma decisões de políticas públicas não foi eleito para esta ação, ou seja, na omissão do Legislativo (bem como inefetividade do Executivo), o Judiciário é quem tem o poder de tomada de decisões relativas ao tema (PINA, 2016).

Diz-se, portanto, que o ativismo revela uma atitude, enquanto a judicialização, uma circunstância de fato (BARROSO, 2008).

Considerando que muitas vezes, a "Justiça" é tardia no país, muitas pessoas, com conhecimento técnico ou não, apoiam decisões ativistas, por enxergarem em tal atividade, uma eficiência que não poderia ser alcançada quando os poderes usam apenas de suas típicas funções. Porém, deve-se pensar: é correto 
que o Poder Judiciário haja além de suas atribuições (por vezes legislando), para justificar um erro que emana do próprio Poder?

\subsubsection{Ativismo Judicial e os Direitos fundamentais}

Há no ordenamento jurídico brasileiro o Princípio da Tripartição dos Poderes ${ }^{4}$, que segundo Alexandre de Moraes (2007, p. 385), traça parâmetros com a finalidade de distinguir as três atribuições do Estado, sendo: legislação, administração e jurisdição, devendo ser atribuída a três órgãos independentes entre si, que com exclusividade as exercerão.

O tema é bastante antigo, tendo sido abordado por diversos filósofos. Aristóteles foi quem primeiro escreveu sobre o assunto, em sua obra "Política". O assunto foi posteriormente mencionado em trabalho de John Locke, que também reconhecia três funções autônomas, e finalmente, Montesquieu elabora a obra "O Espírito das Leis", a quem deve-se a divisão clássica, tornando-se Princípio fundamental da organização política liberal, sendo aclamado no artigo 16 da Declaração dos Direitos do Homem e do Cidadão, de 1.789 (MORAES, 2007, p. 385).

Montesquieu (1993, p. 181) bem definiu o conceito do referido Princípio: "Tudo estaria perdido se o mesmo homem ou o mesmo corpo dos principais ou dos nobres, ou do povo, exercesse esses três poderes: o de fazer as leis, o de executar as resoluções públicas, e o de julgar os crimes ou as divergências dos indivíduos".

A separação dos poderes atinge sua finalidade principal quando garante a correta aplicação das garantias individuais dos cidadãos.

Todavia, diante da inércia dos poderes Legislativo e Executivo em cumprir suas atribuições, o Judiciário vê-se assistido de razão e toma para si, funções dos citados poderes.

Entretanto, há que ressaltar que não cabe aos juristas, visando atender a anseios sociais, interpretar a Lei de forma duvidosa.

Desta feita, o autor e Ministro brasileiro Luís Roberto Barroso, em sua obra "Judicialização, ativismo judicial e legitimidade democrática" (2008, p. 1016) aponta três problemas quando da atuação de um judiciário ativista, quais sejam: os riscos para a legitimidade democrática; politização indevida da justiça; e limites da capacidade institucional do Poder Judiciário.

No que se refere à primeira situação, afirma o Ministro que os membros do Poder Judiciário não são eleitos pelo povo, logo, não possuem legitimidade democrática para a tomada de decisões, vez que o Estado é constitucional e

\footnotetext{
${ }^{4}$ Art. $2^{\circ}$ São Poderes da União, independentes e harmônicos entre si, o Legislativo, o Executivo e o Judiciário.
} 
democrático (onde o poder é fundado na vontade do povo), logo, podem surgir situações de conflitos aparentes.

Em relação ao risco de politização da justiça, declara o autor que uma decisão judicial não pode ser política ao ponto de o jurista entender ter livre escolha, e/ou absoluta discricionariedade, mas ao contrário: nas decisões em que se tenha mais de uma solução aplicável, deve o juiz buscar aquela que seja mais correta e justa à luz da Lei (respeitando a presunção de validade das leis) e do caso concreto.

No que tange aos limites da capacidade institucional do Judiciário, o autor apresenta o Princípio da Tripartição dos Poderes, em que as funções de legislar, julgar e administrar são expressamente direcionadas a três órgãos distintos, independentes e especializados.

Desse modo, quando um dos Poderes assume atribuições típicas de outro, além de não ser respeitado o referido Princípio, coloca-se em risco a efetividade da decisão, vez que em muitas situações pode não ter o juiz, o arbítrio mais qualificado para sanar tal deficiência. Em resumo: "o Judiciário quase sempre pode, mas nem sempre deve interferir" (BARROSO, 2008, p. 16).

Ademais, em visita ao Brasil, em 2009, Antonin Scalia ${ }^{5}$ afirmou que questões referentes aos direitos fundamentais são políticas, desse modo, não cabe aos juristas decidi-las: "A única maneira de decidir uma questão moral é pelo processo democrático. Um juiz não sabe mais do que um cidadão comum". Afirma ainda, o ilustre Magistrado que a Constituição de um país não deve ser estática, mas ao contrário: deve acompanhar a evolução.

Entretanto, decisões "cheias de valores" devem ser tomadas pelo Legislativo (que representa a vontade do povo), e não por um juiz não-eleito (COUTINHO, 2009).

Desse modo, entende-se que limites existem e devem ser respeitados, ainda que a superação destes seja respaldada em assegurar garantias fundamentais, pois, não cabe a um órgão que não possui legitimidade democrática, tomar decisões (que atingirão diretamente a população) pertencentes a outro Poder.

\section{PRINCÍPIO DA PRESUNÇÃO DE INOCÊNCIA}

\subsection{Definição}

O Princípio da Presunção de Inocência ${ }^{6}$, previsto legalmente em nossa

\footnotetext{
${ }^{5}$ Antonin Scalia (1936-2016) foi um juiz associado da Suprema Corte dos Estados Unidos de setembro de 1986 até sua morte em fevereiro de 2016. Era um grande jurista, e considerado politicamente muito conservador.

${ }^{6}$ Presunção de não culpabilidade e estado de inocência são denominações tratadas como sinônimas
} 
Carta Magna entre as garantias constitucionais ${ }^{7}$, é um dos princípios basilares do ordenamento jurídico vez que tutela a liberdade individual, garantindo que ninguém pode ser considerado culpado antes do momento em que transite em julgado a sentença penal condenatória.

Assim, exige-se que as penalidades só podem ser impostas após tornar-se irrecorrível a condenação do agente (JESUS, 2015, p. 53).

Tal garantia, assegura ao acusado julgamento justo respeitando o devido processo legal, e assegura um direito fundamental ao sujeito de direitos dentro da relação processual. Nesse diapasão, nos asseguram Nestor Távora e Rosmar Rodrigues Alencar $(2015$, p. 51) a liberdade, em tese é a regra, situação em que se recorrerá à prisão apenas em casos de extrema exceção:

De tal sorte, o reconhecimento da autoria de uma infração criminal pressupõe sentença condenatória transitada em julgado (art. $5^{\circ}$, inc. LVII, da CF). Antes deste marco, somos presumivelmente inocentes, cabendo à acusação o ônus probatório desta demonstração, além do que o cerceamento cautelar da liberdade só pode ocorrer em situações excepcionais e de estrita necessidade. Neste contexto, a regra é a liberdade e o encarceramento, antes de transitar em julgado a sentença condenatória, deve figurar como medida de estrita exceção.

Através do referido Princípio, derivam duas outras regras essenciais: a de juízo ou probatória, que incumbe ao acusador a ação de evidenciar a culpabilidade do acusado (e não este, de comprovar sua inocência), e a regra de tratamento, que garante que ninguém pode ser considerado culpado senão em virtude de sentença penal condenatória transitada em julgado, desse modo, impede-se qualquer antecipação de culpabilidade ou de juízo condenatório.

De acordo com Aury Lopes Júnior (2014, p. 220), o Princípio possui duas dimensões: uma interna e outra externa.

No que tange a primeira, afirma o autor, que é regra de tratamento imposta ao juiz, determinando que todo o arcabouço probatório seja de responsabilidade do acusador (pois se o réu é presumidamente inocente, nada precisa comprovar), bem como, assegura restrições ao uso (ou abuso) de prisões cautelares.

Em relação à dimensão externa, ensina o citado autor que o Princípio garante o respeito aos limites à exploração midiática abusiva em relação ao fato

pela doutrina moderna.

${ }^{7}$ Art. $5^{\circ}$ Todos são iguais perante a lei, sem distinção de qualquer natureza, garantindo-se aos brasileiros e aos estrangeiros residentes no País a inviolabilidade do direito à vida, à liberdade, à igualdade, à segurança e à propriedade, nos termos seguintes: [...]

LVII - ninguém será considerado culpado até o trânsito em julgado de sentença penal condenatória; $[\ldots]$ 
criminoso e ao próprio processo, bem como, contra uma estigmatização precoce do réu (LOPES JÚNIOR, 2014, p. 220).

É notório que o Estado tem interesse e o direito de punir aqueles que tenham atitudes contrárias à lei, aplicando sanções para tais agentes. Todavia, o direito-dever que o Estado tem de punir deve respeitar a liberdade individual, considerando que este é um bem jurídico o qual o indivíduo não pode ser privado, senão em total atenção aos limites legais.

Desse modo, ante o cometimento de ato ilícito, para ser possível a aplicação de uma pena, o Estado deve respeitar o provável autor do referido ato, conferindo-lhe as garantias constitucionais, e por conseguinte, que este realize sua defesa, não tendo a liberdade cerceada. Assim, faz-se necessário que ocorra um processo, e antes da sentença transitada em julgado e com sua culpabilidade corroborada pelo Estado, o suposto autor é presumidamente inocente.

\subsection{Aspectos históricos}

Apesar de a primeira ideia do referido Princípio ter se dado ainda no Direito Romano, o mesmo fora amplamente atacado e até mesmo invertido na Idade Média, no qual dominava o sistema inquisitório, período em que o acusado era tido como um objeto do processo, razão pela qual, a insuficiência de provas era equivalente a uma "semiprova" da culpabilidade do agente, desse modo, a prisão era a regra (LOPES JÚNIOR, 2014, p. 215).

O Princípio aparece novamente no artigo $9^{\circ}$ da Declaração Universal dos Direitos do Homem e do Cidadão (1789), amparada por ideais Iluministas (movimento que teve à frente filósofos como Montesquieu e Rousseau), que previa que: "Todo acusado é considerado inocente até ser declarado culpado e, se julgar indispensável prendê-lo, todo o rigor desnecessário à guarda da sua pessoa deverá ser severamente reprimido pela lei".

Posteriormente, a Assembleia Geral das Nações Unidas, já em 1948, promulga a Declaração Universal dos Direitos Humanos, que proclama novamente o Princípio em seu artigo 11:

1. Todo ser humano acusado de um ato delituoso tem o direito de ser presumido inocente até que a sua culpabilidade tenha sido provada de acordo com a lei, em julgamento público no qual lhe tenham sido asseguradas todas as garantias necessárias à sua defesa.

2. Ninguém poderá ser culpado por qualquer ação ou omissão que, no momento, não constituíam delito perante o direito nacional ou internacional. Também não será imposta pena mais forte de que aquela que, no momento da prática, era aplicável ao ato delituoso (1948).

Já no Brasil, a ideia foi adotada na Constituição Federal de 1988, em seu 
artigo $5^{\circ}$, inciso LVII que: "ninguém será considerado culpado até o trânsito em julgado de sentença penal condenatória".

Ademais, a presunção de inocência é contemplada no Pacto de San José da Costa Rica, em seu artigo $8^{\circ}$, segunda parte ${ }^{8}$. Tal documento fora ratificado pelo Brasil em setembro de 1992, tendo validade no ordenamento jurídico a partir do Decreto $n^{\circ}$ 678, de 06 de novembro de 1992.

O Princípio apresenta-se ainda no artigo 283 do Código de Processo Penal $^{9}$ (com redação dada pela Lei $n^{\circ} 12.403$, de 2011) sendo este, uma complementação da regra prevista em nossa Carta Magna.

\subsection{Presunção de inocência e o julgamento do réu}

Segundo Ferrajoli (1997, apud LOPES JÚNIOR, 2014, p. 217) a presunção de inocência é decorrente do princípio da jurisdicionalidade, vez que a jurisdição é a atividade essencial à obtenção da prova do delito cometido por alguém, até que não seja produzida tal prova - através do devido processo legal - nenhum delito poderá ser imputado, logo ninguém poderá ser considerado culpado e submetido a uma pena.

$\mathrm{O}$ autor aprofunda o tema dizendo que o princípio é fundamental para a civilização, pois é fruto de uma garantia que tutela a imunidade de inocentes, mesmo que para tal, seja necessário correr o risco de que alguém culpável saia impune. Isso porque o maior interesse deve se valer da ideia de que todos os inocentes, sem restrições, estejam protegidos (FERRAJOLI, 1997, apud LOPES JÚNIOR, 2014, p. 217)

Considerando que os cidadãos estão em constante ameaça pelos infratores, estes também o estão pelo perigo de atribuição de penas arbitrárias.

Desse modo, tem-se a ideia de que a presunção de inocência não é apenas uma garantia de liberdade, mas também uma garantia de segurança (ou defesa social), vez que esta segurança é oferecida pelo Estado, e se manifesta na confiança do povo na Justiça. É defesa, portanto, ao arbítrio quando da aplicação de sanções.

De tal sorte, a constatação da autoria de um crime pressupõe que haja uma sentença penal condenatória transitada em julgada, pois antes de tal marco, o acusado é presumivelmente inocente, cabendo ao acusador, o ônus probatório.

\footnotetext{
${ }^{8}$ Artigo $8^{\circ}-$ Garantias judiciais

$[\ldots]$

2. Toda pessoa acusada de um delito tem direito a que se presuma sua inocência, enquanto não for legalmente comprovada sua culpa. [...]

${ }^{9}$ Art. 283. Ninguém poderá ser preso senão em flagrante delito ou por ordem escrita e fundamentada da autoridade judiciária competente, em decorrência de sentença condenatória transitada em julgado ou, no curso da investigação ou do processo, em virtude de prisão temporária ou prisão preventiva.
} 
Mesmo porque, o encarceramento como medida cautelar só pode ocorrer em medidas extremamente excepcionais e de estrita necessidade. Neste diapasão, a liberdade é a regra e o encarceramento antes de transitada em julgada a sentença condenatória, é medida de exceção (TÁVORA; ALENCAR, 2015).

Cabe realce o fato de que, como mencionado, as prisões cautelares não ferem a presunção de inocência, desde que observados os requisitos legais para tal. Sobre o tema, Aury Lopes Júnior. (2014, p. 804-805) bem leciona ao mencionar que o que garante, de fato, a aplicação das prisões cautelares sem que se fira o Princípio em comento, é a observância do requisito fumus commissi delicti (probabilidade de existência de um fato aparentemente punível) e do fundamento periculum libertatis (perigo que decorre do estado de liberdade do imputado).

Ademais, afirma o autor que a eficácia dos requisitos mencionados, somada à obediência aos demais princípios norteadores das próprias prisões cautelares - como o da Provisionalidade, Provisoriedade, Excepcionalidade, e da Proporcionalidade - é o que garante a condição de coexistência das prisões cautelares com a presunção de inocência (LOPES JÚNIOR, 2014, p. 806).

Quando se admite que o Princípio não seja de fato observado, em qualquer que seja a condição, a sociedade fica à mercê de retroagir a um período de total domínio do Estado, como bem pontua Moraes (2017, p. 91):

Dessa forma, há a necessidade de o Estado comprovar a culpabili-
dade do indivíduo, que é constitucionalmente presumido inocente,
sob pena de voltarmos ao total arbítrio estatal, permitindo-se o odio-
so afastamento de direitos e garantias individuais e a imposição de
sanções sem o devido processo legal e a decisão definitiva do órgão
competente

Outrossim, não deve ser descartada a possibilidade de erro do Poder Judiciário, o que respeitosamente, é sabido que ocorre, e muito. Não são poucas as notícias de sujeitos que passaram dias, meses e até mesmo anos, encarcerados e tiveram sua inocência comprovada e respaldada em erro da máquina judiciária.

Como exemplo, tem-se o caso de Júnior Gomes da Silva, jovem pobre, morador de rua, preso em 2014 acusado de homicídio, situação em que o corpo foi decapitado, carbonizado e ocultado. Júnior permaneceu mais de três anos em cárcere, afirmando ser inocente. Somente foi possibilitada sua liberdade em 2017, quando uma advogada da Comissão de Direito Penal e Penitenciário da OAB-CE, ao analisar documentos das cadeias da região, constatou que duas pessoas com nomes idênticos, em cadeias distintas, cumpriam pena pelo mesmo crime. Ao analisar o caso, fora constatado o erro: Júnior Gomes da Silva, que cumpria pena em Juazeiro do Norte/PR havia sido preso por engano, e permanecia em tal condição há três anos e quatro meses (GLOBO, 2017). 
Ou ainda, pode-se citar o caso do jovem Hércules de 23 anos que passou um ano e um mês preso acusado do crime de roubo, tendo como única prova, o fato de ser amigo em determinada rede social daquele que receptou as rodas do veículo. Na situação, uma testemunha do fato ao visualizar a foto de Hércules mencionou pensar ser ele o autor do crime, vez que era "negro, baixo e "troncudo'. Insta salientar que no caso em tela, nem mesmo o fato de o ladrão de carros (o que se parecia com Hércules) ter sido preso tempos depois, foi suficiente para que a Justiça reconhecesse o engano. Somente após mais de um ano, o Ministério Público pediu a absolvição do rapaz por falta de provas (PRAGMATISMO POLÍTICO, 2017).

Por fim, cabe trazer à baila o caso de Eugênio Fiúza, que após ser confundido com o real "maníaco do Anchieta" passou longos dezoito anos em cárcere, respondendo por diversos crimes de estupro cometidos pelo real criminoso. O verdadeiro maníaco só foi preso anos depois de Eugênio, situação em que foi condenado a nove anos de prisão, ou seja, cumprirá ainda menos tempo do que alguém inocente (só para registro) (PORTAL DO AÇO, 2017).

Ademais, o problema todo do cumprimento de pena antes do trânsito em julgado da decisão penal condenatória não se limita apenas às hipóteses de erro do Judiciário, mas também nos diversos casos em que o acusado tem a ordem concedida em Habeas Corpus impetrados em instâncias extraordinárias.

Como exemplo, tem-se caso extremamente recente de julgado do Superior Tribunal de Justiça (BRASIL, 2017):

PENAL. HABEAS CORPUS SUBSTITUTIVO DE RECURSO PRÓPRIO. INADEQUAÇÃO. ROUBO DUPLAMENTE CIRCUNSTANCIADO. COMPENSAÇÃO PARCIAL ENTRE A ATENUANTE DA CONFISSÃO ESPONTÂNEA E A AGRAVANTE DA REINCIDÊNCIA. ILEGALIDADE NÃO EVIDENCIADA. PRESENÇA DE MAIS DE UMA CAUSA DE AUMENTO. MAJORAÇÃO ACIMA DO MÍNIMO LEGAL. AUSÊNCIA DE FUNDAMENTAÇÃO CONCRETA. SÚMULA 443/STJ. ORDEM NÃO CONHECIDA E HABEAS CORPUS CONCEDIDO DE OFÍCIO.

1. Esta Corte e o Supremo Tribunal Federal pacificaram orientação no sentido de que não cabe habeas corpus substitutivo do recurso legalmente previsto para a hipótese, impondo-se o não conhecimento da impetração, salvo quando constatada a existência de flagrante ilegalidade no ato judicial impugnado.

2. A individualização da pena é uma atividade vinculada a parâmetros abstratamente cominados pela lei, sendo permitido ao julgador, entretanto, atuar discricionariamente na escolha da sanção penal aplicável 
ao caso concreto, após o exame percuciente dos elementos do delito, e em decisão motivada. Dessarte, ressalvadas as hipóteses de manifesta ilegalidade ou arbitrariedade, é inadmissível às Cortes Superiores a revisão dos critérios adotados na dosimetria da pena.

3. No julgamento do Recurso Especial Representativo de Controvérsia n. 1.341.370/MT, em 10/4/2013, a Terceira Seção firmou o entendimento de que, observadas as especificidades do caso concreto, "é possível, na segunda fase da dosimetria da pena, a compensação da atenuante da confissão espontânea com a agravante da reincidência". 4. Na hipótese, tratando-se de réu multirreincidente deve ser reconhecida a preponderância da agravante prevista no art. 61, I, do Código Penal, sendo admissível a sua compensação proporcional com a atenuante da confissão espontânea, em estrito atendimento aos princípios da individualização da pena e da proporcionalidade.

5. A sentença aplicou fração superior a $1 / 3$ (um terço) para majorar a pena apenas em razão das duas causas de aumento reconhecidas, sem apoio em elementos concretos do delito. Forçoso destacar, ainda, que, nos termos da jurisprudência desta Corte, o emprego de arma de fogo, por si só, não justifica aumento superior ao mínimo legal de 1/3 (um terço), incidindo, portanto, à espécie, o entendimento da Súmula 443 desta Corte: "O aumento na terceira fase de aplicação da pena no crime de roubo circunstanciado exige fundamentação concreta, não sendo suficiente para a sua exasperação a mera indicação do número de majorantes". Precedente.

6. Habeas corpus não conhecido. Ordem concedida, de ofício, a fim de reduzir a pena imposta ao paciente José Gabriel a 6 anos de reclusão, mais 14 dias-multa, e aquela estabelecida ao paciente Willian a 6 anos, 2 meses e 20 dias de reclusão, e pagamento de 14 dias-multa, mantendo-se, no mais, o teor da condenação. (STJ. HC 342486/SP. QUINTA TURMA. Relator: Ministro Ribeiro Dantas. Dje 25/10/2017)

Outrossim, é de observar que o mesmo ocorre no Supremo Tribunal Federal (BRASIL, 2013). No caso abaixo, o Habeas Corpus é concedido no sentido de excluir a tipicidade do ato, ou seja, nem mesmo houve crime:

PRINCÍPIO DA INSIGNIFICÂNCIA - IDENTIFICAÇÃO DOS VETORES CUJA PRESENÇA LEGITIMA O RECONHECIMENTO DESSE POSTULADO DE POLÍTICA CRIMINAL - CONSEQUENTE DESCARACTERIZAÇÃO DA TIPICIDADE PENAL EM SEU ASPECTO MATERIAL - TENTATIVA DE FURTO PRIVILEGIA- 
DO (CP, ART. 155, $\S 2^{\circ}$, C/C O ART. 14, II) - "RES FURTIVAE" NO VALOR (ÍNFIMO) DE R \$ 30,00 (EQUIVALENTE A 4,42\% DO SALÁRIO MÍNIMO ATUALMENTE EM VIGOR) - DOUTRINA CONSIDERAÇÕES EM TORNO DA JURISPRUDÊNCIA DO SUPREMO TRIBUNAL FEDERAL - "HABEAS CORPUS" CONCEDIDO. O POSTULADO DA INSIGNIFICÂNCIA E A FUNÇÃO DO DIREITO PENAL: "DE MINIMIS, NON CURAT PRAETOR". - O sistema jurídico há de considerar a relevantíssima circunstância de que a privação da liberdade e a restrição de direitos do indivíduo somente se justificam quando estritamente necessárias à própria proteção das pessoas, da sociedade e de outros bens jurídicos que lhes sejam essenciais, notadamente naqueles casos em que os valores penalmente tutelados se exponham a dano, efetivo ou potencial, impregnado de significativa lesividade. - O direito penal não se deve ocupar de condutas que produzam resultado, cujo desvalor - por não importar em lesão significativa a bens jurídicos relevantes - não represente, por isso mesmo, prejuízo importante, seja ao titular do bem jurídico tutelado, seja à integridade da própria ordem social. O PRINCÍPIO DA INSIGNIFICÂNCIA QUALIFICA-SE COMO FATOR DE DESCARACTERIZAÇÃO MATERIAL DA TIPICIDADE PENAL. - O princípio da insignificância - que deve ser analisado em conexão com os postulados da fragmentariedade e da intervenção mínima do Estado em matéria penal - tem o sentido de excluir ou de afastar a própria tipicidade penal, examinada esta na perspectiva de seu caráter material. Doutrina. Precedentes. Tal postulado - que considera necessária, na aferição do relevo material da tipicidade penal, a presença de certos vetores, tais como (a) a mínima ofensividade da conduta do agente, (b) a nenhuma periculosidade social da ação, (c) o reduzidíssimo grau de reprovabilidade do comportamento e (d) a inexpressividade da lesão jurídica provocada - apoiou-se, em seu processo de formulação teórica, no reconhecimento de que o caráter subsidiário do sistema penal reclama e impõe, em função dos próprios objetivos por ele visados, a intervenção mínima do Poder Público. (STF. HC 115246/MG. SEGUNDA TURMA. Relator: Ministro Celso de Mello. DJe 28/05/2013)

Além do mais, no relatório final do Projeto "Panaceia universal ou remédio constitucional? Habeas Corpus nos Tribunais Superiores", publicado pela FGV Rio em 2014, coordenado pelo Dr. Thiago Bottino (p. 59), apurou-se que entre os anos de 2008 e 2012 houve o julgamento de mais de cento e noventa e cinco mil habeas corpus no Superior Tribunal de Justiça e no Supremo Tribunal Federal, desses, foram analisados $5 \%$, nos quais se chegou a conclusão de que no Supremo Tribunal Federal a concessão da ordem (total ou parcial) alcança o percentual de $8,27 \%$. Esse número chega a $27,86 \%$ no STJ. Ainda, foi concluído que 
esse percentual ultrapassa os $50 \%$ quando a ilegalidade das decisões anteriores decorre de temas que repercutem diretamente na execução da pena.

Desse modo, vê-se que é um erro grotesco e gigante antecipar o cumprimento de pena para antes do trânsito em julgado (momento este defendido na Constituição Federal, como garantia fundamental), ainda mais, quando respaldado na lentidão do Poder Judiciário em aplicar as sanções penais. Não é correto que os cidadãos tenham de pagar o preço pela morosidade do Estado, vez que concordando com isso, estaria se confirmando que os fins justificam os meios.

Deve-se considerar ainda que o Judiciário deve resolver suas questões apoiado em fundamentação jurídica, e não política - como tem feito.

Lênio L. Streck (2016), bem define tal situação, afirmando ainda que cabe ao Legislativo legislar, e ao Judiciário aplicar tal Lei, considerando que é ele o guardião da Constituição. O autor vai além, ao afirmar que "o Direito [...] não seja corrigido por argumentos políticos/morais e que sejam respeitados os limites semânticos, mormente os do texto constitucional".

Como sabido, o julgamento foi inspirado em clamor social, ante a atual situação política do país, sem que fossem ponderadas as consequências do novo entendimento em relação àquelas demandas que não têm foro federal em Curitiba.

A decisão levará, nos anos seguintes, à outras inúmeras decisões equivocadas, pelas quais sentenças desproporcionais, ilegais e injustas serão cumpridas parcial ou totalmente e, no fim, serão reformados pelo Superior Tribunal de Justiça ou pelo próprio Supremo. Todavia, essas causas, não estarão em evidência e, desse modo, ninguém se importará.

\section{DA DECISÃO PROFERIDA NO HABEAS CORPUS No 126.292}

\subsection{Caso que deu ensejo ao Habeas Corpus no 126.292}

Inicialmente, insta salientar que, quando o assunto em comento é o $\mathrm{Ha}$ beas Corpus $\mathrm{n}^{\circ} 126.292$, muitos (apoiadores ou não da nova decisão), ao debaterem o tema sequer imaginam de qual seja o caso que ensejou a decisão.

Adianta-se que referida situação trata-se de momento em que o Supremo Tribunal Federal, revestindo-se de um Ativismo Judicial sem precedentes, julgou de forma contrária à Constituição, mudando entendimento pacificado há anos.

Tal acontecimento deu-se em momento em que o Brasil passa por devasta crise política e judicial, razão pela qual, o novo posicionamento é acolhido e apoiado por diversas pessoas, com conhecimento técnico, ou não, que enxergam na decisão o fim da impunidade para aqueles que cometem crimes políticos, 
os chamados crimes de colarinho branco - pelo qual pessoas de grande importância na sociedade incorrem em delitos, através de "fraudes e outras tramoias [...] para desviar dinheiro" (RODRIGUES, 2017).

Todavia, como se verá a seguir, o crime que deu ensejo ao novo posicionamento do Tribunal, nem mesmo se compara à referida modalidade de crimes citada, como supõe os defensores da decisão.

Tudo teve início em 29 de março de 2011, na cidade de Itapecerica da Serra/SP, onde dois jovens (M.R.D. e A.S.L.) ${ }^{10}$ foram denunciados pelo Ministério Público pelo cometimento do crime de roubo qualificado. Ambos foram presos preventivamente, porém tiveram as prisões revogadas ao longo do processo, chegando ao julgamento livres.

A sentença datada de 28 de junho de 2013 condenou ambos os agentes: A.S.L. com pena de 6 anos e 8 meses, e M.R.D. com pena de 5 anos e 4 meses. $\mathrm{O}$ primeiro teve sua prisão decretada. Entretanto, permitiu o juiz, não enxergando periculosidade em M.R.D., que este recorresse em liberdade. O Ministério Público contentou-se com a decisão e não interpôs recurso. Ambos os agentes apelaram ao Tribunal de Justiça de São Paulo.

Neste ponto já resta evidente que M.R.D. não é "do colarinho branco", mas ao contrário: jovem pobre, filho de empregada doméstica da casa de uma advogada que agiu em sua defesa. Vale esclarecer que a execução provisória não é para culpabilizar quem comete crimes de colarinho branco, poderia de fato ser, mas os números ${ }^{11}$ mostram que a maioria esmagadora de pessoas atingidas com a nova decisão, é de pessoas como M.R.D.

Um ano e três dias depois, os autos chegam ao Tribunal de Justiça do Estado de São Paulo, situação em que a apelação de ambos é julgada - e negada, A.S.L. que já estava preso, manteve-se.

Todavia, a estranheza se encontra no fato de que, ainda que transitada em julgado a condenação para o Ministério Público e havendo apenas apelação de M.R.D., o mesmo além de não ter seu recurso provido, teve a prisão decretada sem nenhuma fundamentação, "de ofício", inclusive em regime fechado, ainda que com a pena inferior a oito anos. Lênio L. Streck (2016) diz que o agente "foi buscar lã e saiu tosquiado".

As advogadas de ambos, em 19 de dezembro de 2014, impetraram $\mathrm{Ha}$ beas Corpus ao Superior Tribunal de Justiça, que indeferiu a liminar, alegando jurisprudência defensiva.

\footnotetext{
${ }^{10}$ Os nomes dos agentes serão preservados por questões éticas.

${ }^{11}$ Ao analisarem pesquisa realizada pelo Dr. Thiago Bottino, sobre os números dos HCs concedidos em instâncias extraordinárias, André Karam Trindade, Lênio Luiz Streck e Juliano Breda chegaram á conclusão de que, no que concerne a "erro na fixação do regime" - situação que atinge diretamente a execução da pena -, os percentuais de decisões reformadas (total ou parcialmente) chega a $62 \%$ nos crimes de roubo. Ademais, quando se evidencia "erro na dosimetria", o percentual alcança 49\%.
} 
Autos ao Ministério Público Federal, que sabiamente, deu parecer favorável à concessão do Habeas Corpus.

Com o referido indeferimento da liminar, as advogadas impetram novo Habeas Corpus, agora ao Supremo Tribunal Federal. Ao analisar o caso em 05 de fevereiro de 2015, o Ministro Teori Zavascki deferiu a liminar, concedendo a ordem. Para tanto, reconheceu que a sentença já havia permitido que o paciente recorresse em liberdade, havendo recurso apenas deste. Mencionou ainda, que o Tribunal de Justiça de São Paulo não apresentou qualquer fundamento ao impor a prisão preventiva, consoante prevê o artigo 312 do Código de Processo Penal, estando a decisão em desacordo com Jurisprudência do Supremo.

Desta feita, teria acabado o caso para M.R.D., que poderia aguardar o julgamento de seus recursos em liberdade, vez que reconhecidas todas as situações anteriormente narradas.

Contudo, sabendo que este caso é o próprio Habeas Corpus 126.292 é de se concluir que, infelizmente, para o paciente, o caso não acaba aqui.

\subsection{A decisão propriamente dita}

O Habeas Corpus foi levado ao Plenário do Supremo Tribunal Federal em 17 de fevereiro de 2016 para se discutir a liminar deferida pelo Ministro Teori Zavascki.

Ocorre que em tal situação, o próprio Ministro, muda decisão e se pronuncia em sentido contrário, votando com a maioria (sete votos a quatro). $\mathrm{Ou}$ seja, M.R.D. volta à prisão - o mesmo que teve o direito de recorrer em liberdade; não tendo interposição de recurso por parte do Ministério Público; sendo preso "de ofício" pelo Tribunal de Justiça de São Paulo; a quem o Ministro reconheceu todas as circunstâncias fáticas e controversas do processo.

Ao decidir pela revogação da liminar, o relator do caso (Min. Teori Zavaski), afirmou que a presunção de inocência se arrasta apenas até o momento em que a decisão proferida em sentença é confirmada em segundo grau de Jurisdição. Todavia, após referido momento, não há mais que se falar em presunção de inocência, isto porque, segundo o Ministro, os recursos cabíveis em instâncias extraordinárias não discutem mais fatos e provas, apenas matéria de direito. E segue o Ministro (BRASIL, 2016):

Ressalvada a estreita via da revisão criminal, é, portanto, no âmbito das instâncias ordinárias que se exaure a possibilidade de exame de fatos e provas e, sob esse aspecto, a própria fixação da responsabilidade criminal do acusado. É dizer: os recursos de natureza extraordinária não configuram desdobramentos do duplo grau de jurisdição, porquanto não são recursos de ampla devolutividade, já que não se 
prestam ao debate da matéria fático-probatória. [...]

Desse modo, resta evidente que o relator votou pelo indeferimento da liminar, ao passo que foi seguido pelos Ministros Edson Fachin, Luís Roberto Barroso, Luiz Fux, Dias Toffoli, Cármen Lúcia e Gilmar Mendes. De outro modo, concluíram pela concessão do Habeas Corpus, abrindo e votando com a divergência a Ministra Rosa Weber e os Ministros Marco Aurélio, Celso de Mello e Ricardo Lewandowski (BRASIL, 2016).

De pronto, já se observa que nem mesmo o relator atentou-se para o previsto no artigo 283 do Código de Processo Penal, não enfrentando o mesmo, a fim de alegar sua constitucionalidade ou não. Lênio L. Streck (2016) bem define a controvérsia da decisão nos seguintes moldes:

Sigo, para indagar: O que fez, afinal, o STF? Além de dar um giro de 180 graus na sua jurisprudência, acabou por sufragar uma prisão decretada fora de qualquer legalidade, circunstância reconhecida pelo MPF e pelo próprio ministro Teori. Ou seja: o ministro Teori concede a liminar com o fundamento de que, além de poder superar a Súmula 691, o TJ-SP não havia fundamentado a prisão em segundo grau. Pois agora ele, juntamente com mais seis ministros, revogam a liminar, só que não fundamentam a necessidade do caso concreto.

Ao analisar o caso, o Supremo deveria ter feito um overruling acerca do entendimento anterior. Um overruling se dá quando um Tribunal entende que deve mudar sua jurisprudência. Para tanto, deve demonstrar o porquê do novo entendimento. Ou seja, além de explicar as fundadas razões que os levaram a tomar tal decisão, devem informar sob qual conjectura o fazem. Em linhas gerais, overruling quer dizer que, o caso que dá ensejo ao novo entendimento deve ser um caso passível de provocar tal reviravolta (STRECK, 2016).

O que se observa atualmente no Supremo Tribunal, é que se tem agido de forma a simpatizar com a Teoria da Katchanga Real.

Explica-se: em linhas gerais, define tal Teoria, que aquele que dá as cartas, é quem dita as regras, vez que sabe tudo, e têm todas as saídas. Contudo, sempre há um "não dito", que é tirado da manga sempre que lhe convém (STRECK, 2012).

De fato, o que mais torna "esdrúxula" a decisão, é que no momento da deliberação do Habeas Corpus, M.R.D. tornou-se um conceito, uma tese, desaparecendo como protagonista do caso. Toda a argumentação levantada em decisão monocrática do relator quando da concessão da liminar, desaparecera. Veja-se que de um recurso interposto apenas pela defesa, fora modificada jurisprudência do Supremo Tribunal Federal, em um caso extremamente simples - e 
ao mesmo tempo complexo - e repleto de erros não sanados. Decisão esta, que atingirá diretamente todos aqueles com condenação em Segundo Grau, ainda que pendente de recurso.

Em 17 de maio de 2016, foram opostos embargos de declaração. Situação em que se afirmou que a decisão apresenta significativa alteração jurisprudencial, vez que os precedentes judiciais possuem "dever de estabilidade", para que se evite mudanças repentinas capazes de atentar contra a segurança jurídica. Ao fim alegou omissão por parte do Supremo, vez que não abordou de forma clara a vigência do artigo 283 do Código de Processo Penal. Os embargos foram rejeitados em 02 de setembro de 2016, sob o fundamento de que não houve qualquer vício na decisão (BRASIL, 2016).

A decisão transitou em julgado, em 14 de fevereiro de 2017, nos mesmos moldes da resolução adotada em fevereiro.

Destarte, desde fevereiro de 2016 está liberada a execução provisória da pena antes do momento previsto na Constituição Federal e no Código de Processo Penal, e suspensa a presunção de inocência.

\subsection{Ações Declaratórias de Constitucionalidade (ADCs) 43 e 44}

Com a decisão proferida pelo Supremo, e o descontentamento de diversos movimentos, o PEN (Partido Ecológico Nacional) e o Conselho Federal da Ordem dos Advogados do Brasil (OAB), ingressaram com duas Ações Declaratórias de Constitucionalidade (que receberam respectivamente, os números $43 \mathrm{e}$ 44), com pedido liminar, visando ao reconhecimento da constitucionalidade da nova redação do artigo 283, caput, ${ }^{12}$ do Código de Processo Penal (incluída pela Lei $\mathrm{n}^{\circ} 12.403$ de 2011).

Em suma, alega o PEN que o dispositivo legal é a única interpretação cabível ao princípio da presunção de inocência, em complemento com a norma prevista no art. $5^{\circ}$, inciso LVII, da Constituição Federal. Menciona o partido que a decisão não é compatível com a norma do Código de Processo Penal, desse modo, para que a pena pudesse ser cumprida já a partir da condenação em Segunda Instância, o Supremo Tribunal Federal deveria ter declarado a inconstitucionalidade do mesmo.

Pedia em caráter cautelar, para que não sobreviessem novas execuções neste sentido, bem como, que fossem suspensas aquelas que já estivessem em curso. Requeria também, que até o julgamento da ADC 43, fossem libertados

\footnotetext{
${ }^{12}$ Art. 283. Ninguém poderá ser preso senão em flagrante delito ou por ordem escrita e fundamentada da autoridade judiciária competente, em decorrência de sentença condenatória transitada em julgado ou, no curso da investigação ou do processo, em virtude de prisão temporária ou prisão preventiva. $[\ldots]$
} 
todos que estivessem em cárcere devido à nova decisão.

Requeria ainda o partido de forma subsidiária - no caso de não acolhimento do primeiro pedido:

Subsidiariamente, caso o primeiro pedido seja indeferido, requer que seja dada interpretação conforme a Constituição ao artigo 283 do CPP para determinar, até o julgamento final da ação, a aplicação das medidas alternativas à prisão previstas no artigo 319 do CPP em substituição ao encarceramento provisório decorrente da condenação em segunda instância.

Ainda subsidiariamente, o partido pede que, se os pedidos cautelares anteriores não forem acolhidos, seja realizada interpretação conforme a Constituição do artigo 637 do CPP, restringindo, enquanto não for julgado o mérito desta ação, a não produção do efeito suspensivo aos recursos extraordinários, e condicionando a aplicação da pena à análise da causa criminal pelo STJ quando houver a interposição do recurso especial (BRASIL, 2016).

A OAB, por sua vez, argumenta que a redação dada pela Lei que introduziu o artigo 283 do Código de Processo Penal buscou justamente, conciliar o processo penal às normas constitucionais. Alega ainda, que o tema tem gerado grande debate e causado controvérsia jurisprudencial, o que, conforme a entidade, ameaça a segurança jurídica. Salienta que, mesmo que a decisão exarada pelo Plenário não tenha efeito vinculante, Tribunais do país todo passaram a adotar igual posicionamento, emitindo decisões que ignoram o disposto no artigo 283 (BRASIL, 2016).

Em 01 de setembro de 2016, o julgamento das ADCs teve início, sendo suspenso logo após o voto do relator, Ministro Marco Aurélio, que deferiu a liminar, afirmando ser constitucional a redação do artigo 283, com a finalidade de que fossem suspensas todas as execuções provisórias após condenação em Segunda Instância. Em seu voto, ao citar o artigo 5º inciso LVII da Constituição, o Ministro reforçou que a redação do artigo é literal, não restando espaços para quaisquer dúvidas sobre a real intenção do legislador (BRASIL, 2016).

No dia seguinte, o Ministro Edson Fachin abriu a divergência, com o escopo de indeferir a liminar. Para tanto, declarou a constitucionalidade do artigo 283, afirmando que este deve ser interpretado conforme a Constituição, afirmando que "é coerente com a Constituição o principiar de execução criminal quando houver condenação confirmada em segundo grau, salvo atribuição expressa de efeito suspensivo ao recurso cabível" (BRASIL, 2016).

O próximo a votar, Ministro Luís Roberto Barroso, seguiu a divergência, votando pelo indeferimento das cautelares, bem como, dos pedidos subsidiários. 
De mesmo modo, o Ministro Teori Zavaski optou por seguir a divergência, afirmando que quando o cumprimento de pena dá-se somente após a análise de recursos em instâncias extraordinárias, o processo penal não alcança sua última finalidade, qual seja a de pacificação social.

Acompanhando o relator, a Ministra Rosa Weber ponderou que o artigo 283 é espelho do artigo $5^{\circ}$, inciso LVII. Afirmou, ainda, que a interpretação dá-se pela semântica das palavras, razão pela qual, não se deve afrontar a clareza do texto.

De maneira oposta, declarou o Ministro Luiz Fux, ao seguir a divergência, que na verdade, é o inciso LXI do artigo $5^{\circ}$ da Constituição ${ }^{13}$ que condiciona o cumprimento de pena em Segundo Grau, e se a vontade do legislador fosse a de condicionar a execução de pena somente após o trânsito em julgado, o teria feito em tal inciso.

Apresentou decisão diferente à exarada no Habeas Corpus 126.292, o Ministro Dias Toffoli, que tinha votado pela execução da pena após condenação em Segunda Instância, acompanhou, em parte o relator. Defendeu o Ministro que o cumprimento antecipado só pode se dar após o julgamento de Recurso Especial pelo Superior Tribunal de Justiça (excluindo a possibilidade quando se tratar de Recurso Extraordinário no Supremo Tribunal Federal). Afirmou por fim, que o critério, é uma forma de impossibilitar o uso exacerbado de recursos e ao, mesmo tempo, a maculação à presunção de inocência.

Ricardo Lewandowski acompanhou o relator, mas de forma integral. Afirmou que o problema não está só no desrespeito à presunção de inocência, mas também, na necessidade de motivar a execução de pena antecipada, vez que não há a correta fundamentação, sendo que, para o Ministro "os tribunais simplesmente confirmam, batem o carimbo na decisão de primeiro grau" (BRASIL, 2016).

Seguiu a divergência o Ministro Gilmar Mendes.

De outro modo, o Ministro Celso de Mello, ao acompanhar o relator afirmou que a presunção de inocência deve prevalecer até o trânsito em julgado, vez que é consequência de longo processo. Ao fim, o Ministro apresentou realce sob o fato de que não pode a inefetividade do sistema processual penal, servir de respaldo para a inobservância de princípio constitucional, sendo a solução mais coerente, a reforma de tal sistema, mas respeitando os direitos fundamentais, principalmente, aqueles fundados do princípio da liberdade.

A última a votar, Ministra Cármen Lúcia, seguiu a divergência confirmando seu entendimento pela execução antecipada da pena, afirmando que o

\footnotetext{
${ }^{13} \mathrm{LXI}$ - ninguém será preso senão em flagrante delito ou por ordem escrita e fundamentada de autoridade judiciária competente, salvo nos casos de transgressão militar ou crime propriamente militar, definidos em lei;
} 
disposto no texto constitucional não descarta a possibilidade de cumprimento da decisão antes do trânsito em julgado.

Desse modo, por seis votos a cinco, manteve-se decisão exarada quando da análise do Habeas Corpus n ${ }^{\circ} 126.292$.

\subsection{Possíveis situações que possam gerar controvérsias com a referida de- cisão}

Em estudo realizado, André Ribeiro da Silva (2016) apresenta alguns problemas quando do cumprimento de pena em momento anterior ao trânsito em julgado da sentença penal condenatória.

Ademais, estudando-se o caso, verificam-se outros problemas que surgirão com o cumprimento da pena após a decisão de segunda instância, sem o trânsito em julgado do processo.

\subsubsection{Do não reconhecimento do privilégio no crime de tráfico de drogas em $1^{\text {a }}$ e $2^{\text {a }}$ Instâncias}

Considere um caso, onde determinado sujeito foi condenado pelo crime de tráfico de drogas - crime hediondo -, sem que lhe fosse reconhecido o privilégio (artigo $33, \S 4^{\circ}$ da Lei $n^{o} 11.343 / 06^{14}$ ) em $1^{\mathrm{a}}$ e $2^{\mathrm{a}}$ Instâncias. Imagine-se que o mesmo é condenado a cinco anos de prisão, e inicie o cumprimento de pena em regime fechado. Todavia, em momento posterior, o privilégio é reconhecido em Instância extraordinária, podendo a pena ser reduzida de um sexto a dois terços, situação em que pode ficar inferior a dois anos, podendo ser cumprida em regime aberto. O que fazer com o tempo que o sujeito ficou encarcerado devido á execução antecipada?

\subsubsection{Progressão do regime no cumprimento de pena}

Considere que certo réu fora condenado a pena de doze anos, com decisão mantida em Segunda Instância havendo, portanto, o cumprimento antecipado

\footnotetext{
${ }^{14}$ Art. 33. Importar, exportar, remeter, preparar, produzir, fabricar, adquirir, vender, expor à venda, oferecer, ter em depósito, transportar, trazer consigo, guardar, prescrever, ministrar, entregar a consumo ou fornecer drogas, ainda que gratuitamente, sem autorização ou em desacordo com determinação legal ou regulamentar:

Pena - reclusão de 5 (cinco) a 15 (quinze) anos e pagamento de 500 (quinhentos) a 1.500 (mil e quinhentos) dias-multa. [...]

$\S 4^{\circ}$ Nos delitos definidos no caput e no $\S 1^{\circ}$ o deste artigo, as penas poderão ser reduzidas de um sexto a dois terços, desde que o agente seja primário, de bons antecedentes, não se dedique às atividades criminosas nem integre organização criminosa.
} 
da pena. Em recurso à Instância extraordinária, a pena do réu é reduzia a sete anos. Neste caso, há nítido prejuízo na progressão do regime, considerando que com a nova pena, o regime inicial a ser adotado, seria o semiaberto.

\subsubsection{Momento para requerer a revisão criminal}

O artigo 621 do Código de Processo Penal ${ }^{15}$ garante a revisão criminal para processos findos, em três situações: quando a sentença foi baseada em provas ou documentos falsos; quando a sentença contraria Lei ou provas do processo; ou quando surjam novas provas de inocência do réu. $\mathrm{O}$ entendimento até então, é de que caberia a revisão somente após o trânsito em julgado da sentença penal condenatória. Todavia, com a nova decisão, quando se poderia ingressar com o pedido de revisão criminal? Após decisão de segundo grau ou somente após o trânsito em julgado do processo?

\subsubsection{Princípio da Insignificância no crime de Descaminho}

É sabido que o Superior Tribunal de Justiça e o Supremo Tribunal Federal adotam entendimentos divergentes quanto ao valor limite á ser aplicado o Princípio da Insignificância no crime de Descaminho ${ }^{16}$. Para o STJ, aplica-se o referido princípio quando a sonegação for até no valor de R\$10.000,00 (dez mil reais). Já para o Supremo o princípio pode ser aplicado, quando o valor iludido não alcance $\mathrm{R} \$ 20.000,00$ (vinte mil reais).

Dito isto, imagine a seguinte situação: o agente é condenado pelo crime de descaminho por ter sonegado $\mathrm{R} \$ 15.000,00$ (quinze mil reais) em impostos. Tanto o juízo de Primeiro Grau, quanto o Tribunal, seguem entendimento do Superior Tribunal de Justiça, ou seja, o réu é condenado e pode dar início ao cumprimento antecipado da pena.

Todavia, imagine que esse mesmo réu, interpõe recurso junto ao Supremo Tribunal Federal, situação em que o Supremo aplicará o Princípio da Insignificância. Terá o réu cumprido pena por crime que sequer existiu.

\footnotetext{
${ }^{15}$ Art. 621. A revisão dos processos findos será admitida:

I - quando a sentença condenatória for contrária ao texto expresso da lei penal ou à evidência dos autos;

II - quando a sentença condenatória se fundar em depoimentos, exames ou documentos comprovadamente falsos;

III - quando, após a sentença, se descobrirem novas provas de inocência do condenado ou de circunstância que determine ou autorize diminuição especial da pena.

${ }^{16}$ Art. 334. Iludir, no todo ou em parte, o pagamento de direito ou imposto devido pela entrada, pela saída ou pelo consumo de mercadoria. [...]
} 


\subsubsection{Indenização decorrente do crime}

Não são raros casos em que a sentença penal condenatória condena a parte vencida em obrigação a ser cumprida na esfera cível. Veja-se que o inciso IV do artigo 387 do Código de Processo Penal (BRASIL, 1941) incumbe ao juiz, que ao proferir sentença deverá fixar "valor mínimo para reparação dos danos causados pela infração, considerando os prejuízos sofridos pelo ofendido".

Para tanto, é fixado no artigo $63^{17}$ do mesmo diploma legal que o momento oportuno para tal, é aquele que sucede o trânsito em julgado da sentença penal condenatória.

Entretanto, considerando que a sentença condene o réu á pagar determinado valor, e que a decisão é mantida em sede recursal. Com o novo entendimento, ainda que pendente a análise de Recurso Especial ou Extraordinário, poderá a vítima ingressar com a execução da sentença penal condenatória no cível para cobrar os valores fixados na sentença?

E se a decisão é reformada pelo Superior Tribunal de Justiça ou pelo Supremo Tribunal Federal, como proceder em face do valor já pago? Caberia uma ação de repetição de indébito?

São todas questões que se levantam com o entendimento atual do Supremo Tribunal Federal, que padecem de respostas concretas, causando a insegurança jurídica que vivemos hoje.

Ademais, não somente essas questões apontadas acima, mas também questões diversas como o caso principal de absolvição pelas Cortes Superiores em sede de recurso.

Insta salientar, que em seu voto, o Min. Luís Roberto Barroso, defende a prisão antes do trânsito em julgado, afirmando que entre janeiro de 2009 e abril de 2016, a quantidade de recursos impetrados às Instâncias Extraordinárias alcançaram números insignificantes.

Apontou o Ministro que no período mencionado, foram providos menos de 3\% dos recursos pelo Supremo, tanto a favor do réu, quanto a favor do Ministério Público. Aponta ainda, que se considerados apenas os recursos providos em favor do réu, o índice alcançado é de 1,1\% (CANÁRIO, 2016).

Todavia, como explanado anteriormente, os números no que toca, exclusivamente, aos Habeas Corpus concedidos atinge percentual consideravelmente superior.

Outrossim, mesmo que não atingisse, pois ainda que haja apenas $1,1 \%$

\footnotetext{
${ }^{17}$ Art. 63. Transitada em julgado a sentença condenatória, poderão promover-lhe a execução, no juízo cível, para o efeito da reparação do dano, o ofendido, seu representante legal ou seus herdeiros.

Parágrafo único. Transitada em julgado a sentença condenatória, a execução poderá ser efetuada pelo valor fixado nos termos do inciso IV do caput do art. 387 deste Código sem prejuízo da liquidação para a apuração do dano efetivamente sofrido.
} 
de recursos providos, há pessoas (de verdade, e não apenas números) que serão gravemente atingidas pelo novo entendimento. Não há que se falar em Justiça, quando essas mesmas pessoas viram apenas estatísticas nas mãos de nossos Juristas.

\section{CONSIDERAÇÕES FINAIS}

Considerando que o Brasil é um Estado Democrático de Direito e que as garantias fundamentais são regras que limitam o poder estatal, tem-se que a interpretação dessas regras deve se dar de maneira constitucional.

Ademais, princípios visam nortear a legislação, bem como as decisões emanadas do Poder Judiciário.

Desse modo, ainda que o Direito exija um elevado grau de autonomia, ignorar a lei cedendo às pressões externas é um luxo ao qual os juristas não se podem entregar, pois não cabe ao Supremo renunciar um Direito individual por razões de política criminal. O Estado deve ser técnico quando da aplicação da norma, para ser justo quando da aplicação da pena.

Assim, tem-se que a decisão proferida no Habeas Corpus $\mathrm{n}^{\circ} 126.292$ contraria a legislação democraticamente aprovada.

Ainda, considerando que a Suprema Corte é também a guardiã da Constituição, não se deve admitir que ultrapassasse os limites semânticos do texto legal para tomar decisões populares, vez que a função do Tribunal não é agradar os demais, mas sim, aplicar a Lei da forma coerente e responsável.

Como bem assegurou Montesquieu em sua obra "O espírito das Leis", datada de 1748: "quando a inocência dos cidadãos não é assegurada, a liberdade também não o é". Desse modo, observa-se que a Presunção de Inocência possui historicidade, não tendo surgido num repente, tendo sobrevivido a ataques inquisidores, inclusive.

Como visto o cumprimento antecipado de pena traz consequências extremamente danosas àqueles atingidos por ela, pois o Judiciário comete erros, por vezes condenando inocentes a cumprirem pena por diversos anos em cárcere.

Ademais, o problema todo não se limita aos erros, vez que como explanado, não são raros os casos de ordem concedida em Habeas Corpus impetrados em Instâncias Extraordinárias, que chega-se a excluir a tipicidade do ato.

O fato é que o Supremo relativizou a presunção de inocência. Todavia, é necessário que se atente para os efeitos paralelos da referida decisão.

Ante o exposto, é de concluir que o Princípio da Presunção de Inocência deve ser analisado de acordo com a norma constitucional, pois é garantia fundamental. Agindo de forma contrária, retroage-se a momento de total arbítrio estatal, o que é extremamente prejudicial ao Estado Democrático de Direito. 


\section{REFERÊNCIAS}

BARROSO, L. R. Constituição, democracia e supremacia judicial: direito e política no Brasil contemporâneo. 2010. Disponível em: < http:// www.luisrobertobarroso.com.br/wp-content/uploads/2017/09/constituicao_ democracia_e_supremacia_judicial.pdf > Acesso em: 13 jul. de 2017.

O Controle de Constitucionalidade no Direito Brasileiro. 3. ed. São Paulo: Saraiva, 2008. . Judicialização, Ativismo Judicial e Legitimidade Democrática. 2008. ConJur. Disponível em: < http://www.conjur.com.br/2008-dez-22/ judicializacao_ativismo_legitimidade_democratica >.Acesso em: 20 out. 2017.

BOTTINO, T. Projeto "Panaceia universal ou remédio constitucional? Habeas corpus nos Tribunais Superiores". 2013. FGV Direito Rio. Disponível em: <https://www.conjur.com.br/dl/radiografia-habeas-corpus.pdf $>$. Acesso em: 11 nov. 2017.

BRASIL. Constituição (1988). Constituição da República Federativa do Brasil: promulgada em 5 de outubro de 1988. Brasília, DF: Senado Federal, 1988.

. Decreto-lei $n^{\circ} 2.848$, de 7 de dezembro de 1940. Código Penal. Diário Oficial República Federativa do Brasil, Brasília, p. 23.911, 31 dez. 1940.

. Decreto-lei no 3.689, de 3 de outubro de 1941. Institui o Código de Processo Penal. Diário Oficial República Federativa do Brasil, Brasília, p. 19.699, 13 out. 1941.

. Superior Tribunal de Justiça. Habeas Corpus $\mathbf{n}^{0}$ 342.486. Pacientes: José Gabriel Gonçalves Júnior e Willian Fernandes. Relator: Ministro Ribeiro Dantas. São Paulo, 19 de outubro de 2017. Disponível em: <https://ww2. stj.jus.br/processo/revista/inteiroteor/?num_registro $=201503005327 \& \mathrm{dt}$ publicacao=25/10/2017> . Acesso em: 11 nov. 2017.

. Supremo Tribunal Federal. Ação Declaratória de

Constitucionalidade $n^{0}$ 43. Requerente: Partido Ecológico Nacional - PEN. Relator: Ministro Marco Aurélio. Distrito Federal, 18 de maio de 2016. Disponível em: $<$ http://www.stf.jus.br/portal/processo/verProcessoAndamento. asp?incidente $=4986065>$. Acesso em: 12 nov. 2017. 
. Supremo Tribunal Federal. Ação Declaratória de

Constitucionalidade $n^{\circ}$ 44. Requerente: Conselho Federal da Ordem dos Advogados do Brasil - CFOAB. Relator: Ministro Marco Aurélio. Distrito Federal, 19 de maio de 2016. Disponível em: <http://www.stf.jus.br/portal/ processo/verProcessoAndamento.asp?incidente $=4986729>$. Acesso em: 12 nov. 2017.

. Supremo Tribunal Federal. Habeas Corpus $\mathbf{n}^{\mathbf{0}}$ 115.246. Paciente: Marta Camilo de Almeida. Relator: Ministro Celso de Mello. Minas Gerais, 28 de maio de 2013. Disponível em: $<$ http://redir.stf.jus.br/paginadorpub/ paginador.jsp?docTP=TP\&docID=4073255 >. Acesso em: 16 nov. 2017.

. Supremo Tribunal Federal. Habeas Corpus $\mathbf{n}^{0}$ 126.292. Paciente: Marcos Rodrigues Dantas. Relator: Ministro Teori Zavaski. São Paulo, 17 de fevereiro de 2016. Disponível em: <http://redir.stf.jus.br/paginadorpub/ paginador.jsp?docTP=TP\&docID=10964246>. Acesso em: 09 nov. 2017.

CANÁRIO, P. Apenas 0,035\% dos recursos ao Supremo absolveram réus, aponta Barroso. ConJur. 2016. Disponível em: $<$ https://www.conjur.com. br/2016-mai-11/apenas-0035-recursos-stf-absolveram-reus-barroso $>$. Acesso em: 17 nov. 2017.

COSTA RICA. Convenção Americana de Direitos Humanos (Pacto de San José de Costa Rica), celebrada em 22 de novembro de 1969. Disponível em: $<$ http://www.pge.sp.gov.br/centrodeestudos/bibliotecavirtual/instrumentos/ sanjose.htm>. Acesso em: 11 nov. 2017.

COUTINHO, F. Visita de Scalia. "Juiz expressa a vontade de Juiz, e não do povo". ConJur. 2009. Disponível em: < https://www.conjur.com.br/2009mai-14/ministro-corte-eua-juizes-nao-podem-decisoes-morais $>$. Acesso em: 05 out. 2017.

CUNHA JÚNIOR, D. Ativismo judicial e concretização dos direitos fundamentais. Brasil Jurídico. 2015. Disponível em: < https://www. brasiljuridico.com.br/artigos/ativismo-judicial-e-concretizacao-dos-direitosfundamentais.-por-dirley-da-cunha-junior.\#_ftn1>. Acesso em: 20 out. 2017.

FRANÇA. Declaração Universal Dos Direitos Humanos. Adotada e proclamada pela Assembleia Geral das Nações Unidas em 10 de dezembro de 1948. Disponível em: <https://www.unicef.org/brazil/pt/resources_10133.htm>. 
Acesso em: 02 nov. 2017.

\section{. Declaração Universal dos Direitos do Homem e do Cidadão.}

Aprovada em 26 de agosto de 1789. Disponível em: <http://www. direitoshumanos.usp.br/index.php/Documentos-anteriores-\%C3\%A0cria $\% \mathrm{C} 3 \% \mathrm{~A} 7 \% \mathrm{C} 3 \% \mathrm{~A} 3 \mathrm{o}-$ da-Sociedade-das-Na\%C3\%A7\%C3\%B5esat\%C3\%A9-1919/declaracao-de-direitos-do-homem-e-do-cidadao-1789.html $>$. Acesso em: 02 nov. 2017.

FERREIRA FILHO, M. G. Curso de Direito Constitucional. 38. ed. rev. e atual. São Paulo: Saraiva, 2012.

G1 CE. Homem é solto após três anos e quatro meses preso por engano no Ceará. G1. 2017. Disponível em: <https://g1.globo.com/ceara/noticia/homeme-solto-apos-tres-anos-e-quatro-meses-preso-por-engano-no-ceara.ghtml?utm source $=$ facebook\&utm_medium $=$ social\&utm_campaign $=g 1>$. Acesso em: 11 nov. 2017.

INOCENTE que passou 18 anos preso tenta manter pensão. Diário do aço. 2017. Disponível em: <http://www.diariodoaco.com.br/ler_noticia. php?id=51401\&t=inocente-que-passou-18-anos-preso-tenta-manter-pensao $>$. Avesso em: 11 nov. 2017.

INOCENTE que ficou 1 ano preso perdeu a namorada, emprego e sonhos. Pragmatismo Político. 2017. Disponível em: < https://www. pragmatismopolitico.com.br/2017/02/inocente-preso-perdeu-namoradaemprego-sonhos.html>. Acesso em: 11 nov. 2017.

KELSEN, H. Jurisdição constitucional. Tradução do alemão: Alexandre Krug; Tradução do italiano: Eduardo Brandão; Tradução do francês: Maria Ermantina Galvão. São Paulo: Martins Fontes, 2003.

JESUS, D. de. Direito penal: parte geral. 36. ed. São Paulo: Saraiva, 2015. v. 1.

LENZA, P. Direito Constitucional Esquematizado. 16. ed. rev. atual. e ampl. São Paulo: Saraiva, 2012.

LOPES JÚNIOR, A. Direito processual penal. 11. ed. São Paulo: Saraiva, 2014.

MORAES, A. de. Direito Constitucional. 21. ed. São Paulo: Atlas, 2007. 
. Direito Constitucional. 33. ed. rev. e atual. até a $E C \mathrm{n}^{\circ} 95$ de 15 de dezembro de 2016. São Paulo: Atlas, 2017.

MENDES, G. F.; COELHO, I. M.; BRANCO, P. G. G. Curso de direito constitucional. 4. ed. rev. e atual. São Paulo: Saraiva, 2009.

MIRANDA, J. Manual de direito constitucional. Lisboa: Coimbra Editora, 2001.

MONTESQUIEU, C. de S. B. de. O Espírito das Leis. Apresentação: Renato Janine Ribeiro. Tradução: Cristina Murachco. São Paulo: Marins Fontes, 1993.

PINA, T. N. de. Ativismo Judicial. In: Âmbito Jurídico, Rio Grande, XIX, n. 145, fev. 2016. Disponível em: <http://www.ambito-juridico.com.br/site/index. php?n_link=revista_artigos_leitura\&artigo_id $=16849$ \&revista_caderno $=9>$. Acesso em: 23 jul. 2017.

POGREBINSCHI, T. Ativismo Judicial e Direito: Considerações sobre o Debate Contemporâneo. Revista Direito, Estado e Sociedade, ${ }^{\circ} 17$, agostodezembro de 2000.

RAMOS, E. S. Ativismo judicial: parâmetros dogmáticos. 2. ed. São Paulo: Saraiva, 2015.

RODRIGUES, S. De onde veio a expressão ‘crime do colarinho branco'? Veja. Disponível em: $<$ http://veja.abril.com.br/blog/sobre-palavras/de-onde-veio-aexpressao-8216-crime-do-colarinho-branco-8217/>. Acesso em: 07 set. 2017.

SCHMITT, C. O guardião da Constituição. Tradução de: Geraldo de Carvalho. Belo Horizonte: Del Rey, 2007.

SILVA, A. J. R. da. Execução de pena em segunda instância: restrição do princípio da presunção de inocência e não culpabilidade. In: Âmbito Jurídico, Rio Grande, XIX, n. 150, jul 2016. Disponível em: <http://ambito-juridico.com. $\mathrm{br} / \mathrm{site} /$ ?n_link=revista_artigos_leitura\&artigo_id=17481>. Acesso em $12 \mathrm{nov}$. 2017.

SILVA, J. A. Curso de direito constitucional positivo. 32. ed. rev. e atual. São Paulo: Malheiros, 2009.

STRECK, L. L. Abandonar as próprias vontades para julgar é o custo da 
democracia. ConJur. 2014. Disponível em: $<$ https://www.conjur.com.br/2014ago-10/entrevista-lenio-streck-jurista-advogado-procurador-aposentado>. Acesso em: 02 out. 2017.

O estranho caso que fez o STF sacrificar a presunção da inocência. ConJur. 2016. Disponível em: <https://www.conjur.com.br/2016-ago-11/ senso-incomum-estranho-fez-stf-sacrificar-presuncao-inocencia $>$. Acesso em: 07 out. 2017.

Katchanga e o bullying interpretativo no Brasil. ConJur. 2012. Disponível em: < https://www.conjur.com.br/2012-jun-28/senso-incomumkatchanga-bullying-interpretativo-brasil>. Acesso em: 11 nov. 2017.

SUPREMO TRIBUNAL FEDERAL. Pena pode ser cumprida após decisão de segunda instância, decide STF. Supremo Tribunal Federal. 2016. Disponível em: $<$ http://www.stf.jus.br/portal/cms/verNoticiaDetalhe. asp?idConteudo=310153>. Acesso em: 09 nov. 2017.

. Ações pedem reconhecimento de norma do CPP que trata da presunção de inocência. Supremo Tribunal Federal. 2016. Disponível em: $<$ http://www. stf.jus.br/portal/cms/verNoticiaDetalhe.asp?idConteudo=317545>. Acesso em: 11 nov. 2017.

TÁVORA, N.; ALENCAR, R. R. Curso de direito processual penal. 10. ed. rev. atual. e ampl. Salvador: JusPodivm, 2015.

TRINDADE, A. K.; STRECK, L. L.; BREDA, J. O lado oculto dos números da presunção de inocência. ConJur. 2016. Disponível em: $<$ https://www.conjur. com.br/2016-jun-13/lado-oculto-numeros-presuncao-inocencia $>$. Acesso em: 09 nov. 2017.

VARGAS. D. Manual de direito constitucional. São Paulo: Revista dos Tribunais, 2010.

\section{PRINCIPLE OF THE PRESUMPTION OF INNOCENCE AND THE DECISION OF THE SUPREME FEDERAL COURT IN HABEAS CORPUS No. 126.292}

ABSTRACT: The constitutional principles are essential to the Brazilian legislation, since they are the basis of the legal system. Among them, the Principle of Presumption of Innocence, which presents the initial framework to start serving 
a sentence, being an indelible clause, and as such, must be analyzed according to the constitutional provisions. Nevertheless, when judging Habeas Corpus No. 126.292, this was not the understanding of the Federal Supreme Court, since it changed the jurisprudence understanding which has been consolidated for years, allowing the sentence to be served before the decision became final. Such event took place in a time when Brazil is undergoing extensive political and legal crisis, reason for which this new positioning is supported by several people, with and without technical knowledge, who think the decision will bring the end of the impunity for those who incur in political crimes, also known as white-collar crimes. However, it is important to point out that the crime that originated the new position of the Court cannot even be compared to the aforementioned criminal mode (with the perpetrator condemned for the crime of aggravated theft). Since the Federal Supreme Court has the duty of safeguarding the Brazilian Constitution, and that, when deeming it as pertinent, the Supreme Courte judges against the constitution in order to attend to social claims (ignoring the applicable Law), it can be considered that it acts in total controversy to its ideals.

KEYWORDS: Constitutionality; Criminal proceedings; Habeas Corpus; Presumption of Innocence.

\section{PRINCIPIO DE LA PRESUNIÓN DE INOCENCIA Y LA DECISIÓN PROFERIDA POR EL SUPREMO TRIBUNAL FEDERAL EN EL HABEAS CORPUS No 126.292}

RESUMEN: Los principios constitucionales son esenciales como fuente del Derecho Brasileño, teniendo como objetivo principal servir de base al ordenamiento jurídico. De este modo, se tiene el Principio de la Presunción de Inocencia, que presenta el marco inicial del cumplimiento de la pena, siendo cláusula pétrea, debe ser analizado de acuerdo con el texto constitucional. Sin embargo, al juzgar al Habeas Corpus $n^{\circ} 126.292$ no fue ese el entendimiento del Supremo Tribunal Federal, ya que modificó de manera diametralmente opuesta entendimiento firmado en Jurisprudencia consolidada desde hace años, permitiendo ahora el cumplimiento de la pena antes de que la sentencia penal condenatoria transitar en juzgado. Tal acontecimiento se dio en el momento en que Brasil pasa por devastar crisis política y judicial, por lo que el nuevo posicionamiento es apoyado por diversas personas, con conocimiento técnico o no, que ven en la decisión el fin de la impunidad para aquellos que cometen los crímenes políticos, los llamados crímenes de "cuello blanco". Sin embargo, se subraya que el crimen que dio lugar al nuevo posicionamiento del Tribunal, ni siquiera se compara a la referida modalidad de crímenes citada (siendo el infractor condenado al crimen de robo cualificado). En el sentido de que el Supremo Tribunal Federal tiene el deber 
de custodia de la Constitución, y que, al parecer pertinente, el Pretorio Excelso juzga de forma inconstitucional a fin de atender a anhelos sociales (ignorando la Norma para ello), se tiene que el mismo actúa en total controversia en cuanto a sus ideales.

PALABRAS CLAVE: Constitucionalidad; Habeas Corpus; Presunción de Inocencia; Principios; Proceso Penal. 